\title{
The History of Traditional Medicine in the Arab Region
}

\author{
Inas Rifaat Ibrahim ${ }^{1 *}$, Mohamed Azmi Hassalii ${ }^{1}$, Fahad Saleem² and Haydar Tukmagi FAl ${ }^{3}$ \\ ${ }^{1}$ Universiti Sains Malaysia, Malaysia \\ ${ }^{2}$ University of Baluchistan, Pakistan \\ ${ }^{3}$ Al-Mustaffa University College, Iran
}

Submission: November 14, 2017; Published: December 06, 2017

*Corresponding author: Inas Rifaat Ibrahim, School of Pharmaceutical Sciences, University Sains Malaysia, 11800 Penang, Malaysia, Email: phm.enas@yahoo.com

\begin{abstract}
Traditional medicine plays an important role in the Arab region. It remains the complement part of the healthcare system of the Arabic society. Historical texts and current investigations indicated that Arab region of the Mediterranean has been characterized through generations with a rich inventory of medicinal plants and folk practices for healing. This in turn made the treatment with traditional medicine a long-standing cultural heritage.
\end{abstract}

Keywords: Arabic peninsula; Medicinal herbs; Tibb Al-Nabawi; Alhijama

\section{Introduction}

Traditional medicine is very popular among the population around the world. It is defined as "any system of healthcare that has ancient roots, cultural bonds, trained healers and a theoretical construct" [1]. The Arab regions have been characterized through generations by an abundant inventory of traditional medicine [2]. Arabs have a long history in understanding the disease and find probable methods for the diagnosis and treatment of different ailments [3]. The traditional medicine in this region of the world consisting mainly of medicinal herbs and some cultural practices. The first evidence of herbal use goes back to the Sumerian civilizations in Iraq (3000-1970 BC) [4]. Prescriptions of herbal remedies were found engraved on cuneiform clay tablet; these were uncovered in 1960 [5]. During the Babylonian period (1970-589), the king Hammurabi has released 285 compulsory rules, one of them specifically indicated to the medicine, herbal use, and medical practice [4]. In the 8th century, traditional medicine has been flourished and physicians' prescriptions included mainly herbal preparations in their crude form for the cure of the disease. During that time, the first pharmacy in the world appeared in Baghdad (the capital of Iraq nowadays) where herbal preparations were dispensed in the form of oils, teas, syrups, ointments, and powders [6]. Among famous physicians (Hakeem) in the Arab world were Al-Razi (850-923 AD) and Ibin Sina or Avicenna (980-1038 AD) who wrote "Al-Qanoon fil-Tib" (Law of medicine) [4]. In addition, the famous botanist and pharmacist was Albetar (1021-1080 AD) [4]. Their books and medical articles maintained a considerable importance to the medical teaching in the West until the end of $16^{\text {th }}$ century [2].

With the emergence of Islam (the dominant religion of this area) in the $7^{\text {th }}$ century AD [7]; a further knowledge about disease prevention and treatment was added in the Arabian Peninsula. A complete system of therapy both for the soul and the body was gifted by the God to the prophet Muhammed. The prophet of Islam [8]. The Quran, the holly book of Islam, has addressed all matters relating to the life and worship. Some versus of the Quran recommend the use of special food such as date and shake towards you the trunk of the palm tree, it will drop on you ripe, fresh dates. Verse (19:25) Surat Maryam; as well as, honey. Then eat from all the fruits and follow the ways of your Lord submissively. There emerges from their bellies a drink, varying in colors, in which there is healing for people, Verse (16:69) Surat Al-Nahil. Other versus, mentioned that reading Quran resulted in healing the soul. O mankind, there has to come to you, instruction from your Lord and healing for what is in the breasts and guidance and mercy for the believers, Verse (10:57) Surat Yunus. With these divine revelations, the prophet Muhammed guided the Muslims to pursue healthy 
habits that lead to a healthy life [9]. The adoption of the prophet therapy in the Arab world was justified as being in congruence with the faith of Islam. Islamic opinions on the treatment and the prophetic traditions were known later by Muslim society as "Tibb Al-Nabawi" [8]. One of the most familiar practices of "Tibb Al-Nabawi" is "Alhijama" which is known as cupping in Western countries. By this practice, the blood is drawn from various points in the body through the concept of applying a vacuum above the skin with a special tool or cup. Soon after removing the vacuum, small incisions are made on the skin using a surgical or razor blade to withdraw the unwanted blood from the body. Generally, traditional healer without formal medical education performs this practice [10]. For hundreds of years, Alhijama maintain popularity among Arab society for several conditions like hypertension, musculoskeletal pain, heart disease, and skin conditions. Yet, controversy about the safety and effectiveness of this practice remains in the scientific medical texts.

In the last decades, traditional medicine has become the interest of the global researchers. Recent investigations suggested that a large-segment of Arabic people rely heavily on traditional medicine to cope with the healthcare need $[11,12]$. The Arab region is distinguished like other areas of the globe into rural and urban societies. People of the large cities and inhabitants of the desserts (the nomads) or those of the remote areas and hilly lands rely largely on the folk practices of medicine $[4,12]$. The geographical diversity of this area and the climate conditions have contributed to considerable differences in its natural herbs. Arab land is covered by more than 2600 plant species, and around 700 of them are used as phytotherapy or botanical pesticides [13]. Latest investigations in Arab countries have demonstrated a potential use of $250-290$ plant species for the treatment and prevention of various diseases [11,13,14]. Herbs in crude form or in a processed state can be purchased easily from "Al Attar" (a small shop for selling herbal preparation to the public), or form food market; to a less extent from pharmacies. To date, the profession of "Al Attar" is inherited form generation to another in the Arab region and considered as not only the main source of herbal remedy, but also for medical consultation.

\section{Conclusion}

It can be concluded that the traditional medicine of Arab region arose from historical, cultural, and religious perspectives. Even though Arab heritage of herbal remedy and some religious practices has contributed greatly to the evolution of Western medicine. Extensive researches are yet required to promote its effectiveness through evidence-bases approach. If this achieved; it could be integrated later with the standard model of health care.

\section{Conflict of interest}

The authors declare that there is no conflicting interest with this work.

\section{References}

1. Truter I (2007) African traditional healers: Cultural and religious beliefs intertwined in a holistic way. SAPJ 74(8): 56-60.

2. Saad B, Azaizeh H, Said O (2005) Tradition and perspectives of Arab herbal medicine: a review. Evid Based Complement Alternat Med 2(4): 475-479.

3. Azaizeh H, Saad B, Cooper E, Said O (2010) Traditional Arabic and Islamic medicine, a re-emerging health aid. Evid Based Complement Alternat Med 7(4): 419-424.

4. Douri ANA (2014) Some important medicinal plants in Iraq. AS] IJAHAM 2(1): 10-20.

5. Ahmed IF, Mohamed IMI, Albert IW (2016) Pharmacy practice in developing countries: Achievements and Challenges. Academic Press, London, United Kingdom.

6. Ibrahim IR, Hassali MA (2014) The practice of pharmacy in Iraq. Health MED Journal 4: 1230-1234.

7. Gordon M (2005) The rise of Islam. Greenwood Publishing Group, Westport, London.

8. Rumkhani AA, Razgan AIM, Faris AIA (2016) TibbOnto: Knowledge representation of prophet medicine (Tibb Al-Nabawi). Procedia Computer Science 82: 138-142.

9. Wakim KG (1944) Arabic medicine in literature. Bull Med Libr Assoc 32(1): 96-104.

10. Inas RI, Mohamed AH, Saleem F (2014) The use of complementary and alternative medicines in hypertension: A summary of the Arab region. Australasian Medical Journal 7: 476-477.

11. Azaizeh H, Saad B, Khalil K, Said O (2006) The state of the art of traditional Arab herbal medicine in the Eastern region of the Mediterranean: a review. Evid Based Complement Alternat Med 3(2): 229-235.

12. Shtayeh AMS, Jamous RM, Salameh NM (2013) Complementary and alternative medicine (CAM) use among hypertensive patients in Palestine. Complement Ther Clin Pract 19(4): 256-263.

13. Saad B, Dakwar S, Said O, Hijleh AG, Battah FA, et al. (2006) Evaluation of medicinal plant hepatotoxicity in co-cultures of hepatocytes and monocytes. Evid Based Complement Alternat Med 3(1): 93-98.

14. Said O, Khalil K, Fulder S, Azaizeh H (2002) Ethnopharmacological survey of medicinal herbs in israel, the golan heights and the west bank region. J Ethnopharmacol 83(3): 251-265. 
This work is licensed under Creative Commons Attribution 4.0 Licens

DOI: 10.19080/JCMAH.2017.04.555634
Your next submission with Juniper Publishers will reach you the below assets

- Quality Editorial service

- Swift Peer Review

- Reprints availability

- E-prints Service

- Manuscript Podcast for convenient understanding

- Global attainment for your research

- Manuscript accessibility in different formats

( Pdf, E-pub, Full Text, Audio)

- Unceasing customer service

Track the below URL for one-step submission https://juniperpublishers.com/online-submission.php 